\title{
STRATEGI KOMUNIKASI PEMASARAN PERSONAL SELLING PADA PKT-KEBUN RAYA BOGOR
}

\author{
Detya Wiryany \\ Fakultas Komunikasi dan Desain, Universitas Informatika dan Bisnis Indonesia \\ detyawiryany@unibi.co.id
}

\begin{abstract}
Abstrak
Kebun Raya Bogor merupakan Pusat Konservasi Tumbuhan yang berada dibawah naungan Lembaga Ilmu Pengetahuan Indonesia (LIPI). Kebun Raya Bogor dalam meningkatkan pelayanannya kepada masyarakat, membentuk Jasa Informasi dan Pelayanan sebagai pusat kegiatan penjualan jasa. Dalam mengoptimalkan kegiatan penjualan jasa maka dibutuhkan peran seorang personal selling dalam melakukan kegiatan pemasaran. Personal selling berperan untuk mempresentasikan dan mempromosikan produk kepada konsumen. Kegiatan personal selling berupa interaksi langsung dengan satu calon pembeli atau lebih untuk melakukan presentasi, menjawab pertanyaan dan menerima pesanan. Hambatan yang dialami oleh personal selling dalam kegiatan penjualan jasa di Kebun Raya Bogor terdiri dari hambatan non-teknis maupun teknis, seperti hambatan komunikasi dan fasilitas yang menunjang kegiatan.

Bisnis yang sukses selalu ditandai dengan tingginya angka penjualan. Marketing satusatunya alasan mengapa sebuah bisnis bisa menghasilkan angka penjualan yang sangat tinggi sementara pesaingnya lebih rendah. Hanya dengan mengenali inti kegiatan marketing, kita bisa mendapatkan penjualan yang optimal bagi bisnis kita.

Komunikasi persuasif adalah komunikasi yang bertujuan untuk mengubah atau memengarui kepercayaan, sikap, dan perilaku seseorang sehingga bertindak sesuai dengan apa yang diharapkan oleh komuniator.

Dalam menyampaikan informasi atau pesan kepada target yang dituju dibutuhkan seorang personal selling dalam mempengruhi konsumen pengguna jasa. Mereka berusaha agar kebanyakan orang dalam target sasaran memberikan respon positif kepada personal selling. Oleh karena itu komunikasi yang dilakukan secara informatif harus dilakukan secara komunikatif, dapat dipaham, dan dimengerti oleh target.
\end{abstract}

Kata-kata kunci: kebun raya bogor, komunikasi persuasif, marketing, personal selling

\begin{abstract}
Bogor Botanical Garden $(B B G)$ is the center of the plants conservation that is under the auspices of scientific institution Indonesia LIPI. In improving service quality to the society BBG, was creating a sub section that oversees the information and services by a personal selling. To optimized personal selling activities, can't be separated from the role of personal selling division. Their roles are to present the personal selling and to promote products to prospective society. Personal selling activities as a direct interaction with the potential customers ere making presentations, promoting and takeing orders. Personal selling have barriers that non technical and technical barriers.

A succesful buisness has always been marked by high sales. Marketing is the only reason why business can generate very high sale while competitor lower. Only by recognizing the core of marketiing activities we can get the optimal sales for our business.

Persuasive communication is, communication that aims to alter or affect the beliefs, attitudes and behaviour of a person acting in accordance with what is expection by communicator.

In presenting information, messages or information to customers which required a personal selling in influencing coustomers servic user. They are traying to made the consumen give a positive responses to personal selling. Therefore communication for information is must do by comunicatif so it can be understood by the consumen.
\end{abstract}

Keywords: bogor botanical garden, persuasive communication, marketing, personal selling 


\section{PENDAHULUAN}

Sejalan dengan perkembangan waktu, berbagai perusahaan lokal maupun nasional bersaing memperkenalkan dan memasarkan barang dan jasa untuk menarik minat masyarakat. Produk berupa jasa dapat membantu konsumen dengan memberikan kemudahan untuk melakukan kegiatan. Produk berupa jasa banyak disajikan oleh objek wisata, hotel, rumah sakit, dan berbagai bentuk usaha lain yang mengedepankan pelayanan kepada konsumen. Kegiatan penjualan jasa yang ditawarkan bersifat komersil maupun nonkomersil, sehingga dibutuhkan peran komunikator dalam memasarkannya.

Bisnis yang sukses selalu ditandai dengan tingginya angka penjualan. Marketing satusatunya alasan mengapa sebuah bisnis bisa menghasilkan angka penjualan yang sangat tinggi sementara pesaingnya lebih rendah. Hanya dengan mengenali inti kegiatan marketing, kita bisa mendapatkan penjualan yang optimal bagi bisnis kita. Menurut (Kotler, 2010) marketing adalah fungsi usaha yang menjabarkan kebutuhan konsumen yang belum terpenuhi pada saat ini dan mengusahakan produk, aktivitas, dan pelayanan apa yang dapat memenuhi kebutuhan.

Komunikasi persuasif adalah suatu proses, yakni proses mempengaruhi sikap, pendapat dan perilaku orang lain, baik secara verbal maupun nonverbal. Proses itu sendiri adalah setiap gejala atau fenomena yang menunjukkan suatu perubahan yang terus-menerus dalam konteks waktu, setiap pelaksanaan atau perlakuan secara terus-menerus. Ada dua persoalan yang berkaitan dengan penggunaan proses, yakni persoalan dinamika, objek, dan persoalan penggunaan bahasa.

Kegiatan pemasaran merupakan proses mempersepsikan, memahami, menstimulasi dan memenuhi kebutuhan pasar sasaran yang dipilih secara khusus dengan menyalurkan sumber-sumber sebuah organisasi terhadap kebutuhan pasar.

Pusat Konservasi Tumbuhan Kebun Raya Bogor (PKT-KRB) adalah salah satu instansi pemerintah yang menawarkan jasa kepada masyarakat. Sub Bagian Jasa dan Informasi yang berperan dalam bidang kehumasan menaungi unit Jasa Informasi dan Pelayanan. Jasa Informasi dan Pelayanan bertugas untuk memberikan informasi dan pelayanan yaitu dalam bentuk penjualan jasa dan fasilitas. Penjualan jasa dalam sebuah perusahaan dipresentasikan oleh personal selling.

Menurut Machfoedz (2010) personal selling adalah presentasi langsung yang dilakukan oleh personil wiraniaga perusahaan dengan tujuan menjual dan menjalin hubungan dengan konsumen. Seorang personal selling yang baik tidak hanya memiliki skill tetapi juga kemampuan komunikasi interpersonal yang baik, karena setiap harinya personal selling selalu berhadapan dengan orang lain.

Personal selling dalam memasarkan produk tentunya berkaitan dengan komunikasi pemasaran. Menuru Machfoedz (2010) Pemasaran modern mengelola sistem komunikasi pemasaran yang kompleks, informasi yang diberikan personal selling tentunya seputar promosi, produk yang dipasarkan, kegunaan produk, manfaat produk dan solusi mengenai apa yang akan dibutuhkan konsumen dalam melakukan kegiatan. Personal selling merupakan alat yang dianggap cukup efektif dalam menyampaikan informasi dan melakukan promosi, terhadap produk jasa yang dijual oleh perusahaan.

Menurut (Suryadi, 2006) Promosi merupakan serangkaian kegiatan untuk mengkomunikasikan, memberi pengetahuan, dan meyakinkan tentang suatu produk kepada banyak orang agar mereka mengakui kehebatan produk tersebut, membeli dan memakainya, juga mengikat pikiran dan perasaan mereka dalam suatu wujud loyalitas terhadap produk.

Kegiatan penelitian dilakukan untuk mengetahui penjualan jasa dan fasilitas serta pemahaman informasi di Kebun Raya Bogor. Kegiatan ini diharapkan dapat menjadi pengetahuan dan memberikan manfaat untuk menunjang perkembangan pengetahuan mengenai tugas dan peranan personal selling dalam memberikan pemahaman kepada konsumen mengenai penjualan jasa dan informasi. Suatu bentuk pemahaman dan keikutsertaan dalam memberikan pelayanan jasa dan informasi di KRB melalui penelitian 
yang telah dilakukan merupakan hal yang penting untuk diketahui dan dilaksanakan.

\section{KAJIAN PUSTAKA Komunikasi Bersifat Informatif}

\section{1) Komunikasi Persuasif}

Menurut Onong Uchjana Effendy komunikasi adalah proses peyampaian pesan oleh seseorang kepada orang lain, untuk memberi tahu, mengubah sikap, pendapat, atau perilaku, baik secara lisan (langsung) atau pun secara tidak langsung (melalui media). Komunikasi pada dasarnya dapat dilakukan oleh setiap makhluk hidup. Keberlangsungan komunikasi juga dapat dimanfaatkan sebagai sumber informasi atas keberadaan produk atau jasa.

Komunikasi persuasif adalah komunikasi yang bertujuan untuk mengubah atau memengarui kepercayaan, sikap, dan perilaku seseorang sehingga bertindak sesuai dengan apa yang diharapkan oleh komuniator. Dalam menyampaikan informasi atau pesan kepada target yang dituju dibutuhkan seorang personal selling dalam mempengaruhi konsumen pengguna jasa. Mereka berusaha agar kebanyakan orang dalam target sasaran memberikan respon positif kepada personal selling. Oleh karena itu komunikasi yang dilakukan secara informatif harus dilakukan secara komunikatif agar dapat dipaham, dan dimengerti oleh target sasaran.

Seorang personal selling yang profesional harus memiliki pengetahuan dan kemampuan yang luas tentang cara berkomunikasi. Komunikasi yang dilakukan oleh personal selling kepada target haruslah bersifat informatif dan sedikit mempersuasif (mengajak).

\section{2) Proses Komunikasi}

Proses komunikasi terbagi menjadi dua tahap, yakni secara primer dan secara sekunder.

a. Proses komunikasi secara primer adalah proses penyampaian pikiran dan atau perasaan seseorang kepada orang lain dengan menggunakan lambang (symbol) sebagai media. Lambang sebagai media primer dalam proses komunikasi adalah bahasa, kial, isyarat, gambar, warna, dan lain sebagainyayang secara langsung mampu menterjemahkan pikiran atau perasaan komunikator kepada komunikan.

b. Proses komunikasi secara sekunder adalah proses penyampaian pesan oleh seorang kepada orang lain dengan menggunakan alat atau sarana sebagai media kedua setelah memakai lambang sebagai media pertama. Seorang komunikator menggunakan media kedua dalam melancarkan komunikasinya. Seperti surat, telfon, fax, surat kabar, radio, televisi, dan film.

\section{3) Pengertian Humas(Public Relations)}

Salah satu definisi Public Relations, yang diambil dari The British Institute of public Relations, berbunyi :

Public Relations activity is management of communications betwen an organization and its publics. (aktivvitas Public Relations adalah mengelola komunikasi antara organisasi dan publiknya)

Menurut Edward L. Bernay, dalam bukunya Public Relations (1952, University of Oklahoma Press), terdapat 3 fungsi utama Humas, yaiu:

a. Memberikan penerangan kepada msayarakat.

b. Melakukan persuasi untuk mengubah sikap dan perbuatan masyarakat secara langsung.

c. Berupaya untuk mengintegrasikan sikap dan perbuatan suatu badan atau lembaga sesuai dengan sikap dan perbuatan masyarakat atau sebaliknya.

Dari pemaparan definisi dan fungsi public relations di atas, dapat ditarik suatu kesimpulan bahwa ciri khas proses dan fungsi Manajemen Humas (Public Relations Management), adalah sebagai berikut:

a. Menunjukan kegiatan tertentu (action)

b. Kegiatan yang jelas (activities)

c. Adanya perbedaan khas dengan kegiatan lain (different)

d. Terdapat suatu kepentingan tertentu (important)

e. Adanya kepentingan bersama (common interest)

f. Terdapat komunikasi dua arah timbal balik (reciprocal two ways traffic communication).

\section{4) Fungsi Public Relations}


Berdasarkan ciri khas kegiatan Humas atau Public Relations tersebut, menurut pakar Humas Internasional, Cutlip \& Centre, and Canfield (1982) fungsi Public Relations dapat dirumuskan sebagai berikut:

a. Menunjukan aktivitas utama manajemen dalam mencapai tujuan bersama (fungsi melekat pada manajemen lembaga/organisasi.

b. Membina hubunan yang harmonis antara badan/organisasi dengan publiknya yang merupakan khalayak sasaran.

c. Mengidentifikasikan segala sesuatu yang berkaitan dengan opini, persepsi dan tanggapan masyarakat terhadap badan/organisasi yang diwakilinya, atau sebaliknya.

d. Melayani keinginan publik dan memberikan sumbangan saran kepada pimpinan atau sebaliknya.

e. Menciptakan komunikasi dua arah timbal balik, dang mengatur arus informasi, publikasi serta pesan dari badan /organisasi ke publiknya atau sebaliknya, demi tercapainya citra positif bagi kedua belah pihak.

\section{5) Sasaran Kegiatan Humas}

Perkembangan profesionalisme Public Relations yang berkaitan dengan perkmbangan peranan PR, baik sebagai praktisi maupun profesional dalam suatu organisasi atau perusahaan, menurut Dozie D.M, (1992) merupakan salah satu kunci untuk memahami fungsi Public Relations dan komunikasi organisasi. Selain itu, hal tersebut juga merupakan kunci untuk pengembangan peranan praktisi PRO (pejabat humas) dan pencapaian profesionalisme dalam Public Elations.

Pencapaian citra positif merupakan tujuan utama dan sekaligus merupakan reputasi dan prestasi yang hendak dicapai bagi dunia hubungan masyarakat. (kehumasan) atau Public Relations. Citra tidak dapat diukur secara atau abstrak (intangible) dan tidak dapat diukur secara matematis, tetapi wujudnya bisa diraskan dari hasil penilaian baik atau buruk.

\section{6) Kualitas Jasa Pelayanan}

Jasa dan pelayanan yang baik dan memuaskan tentunya sangat diharapkan oleh konsumen, harapan konsumen satu dan yang lain nya tentunya berbeda walaupun pelayanan yang diberikan secara konsisten. Kualitas mungkin dapat dilihat sebagai suatu kelemahan jika konsumen mempunyai harapan yang terlalu tinggi, walaupun dengan suatu pelayanan yang baik.

\section{7) Karakteristik Jasa Pelayanan}

Tidak dapat diraba (intangibility) Jasa adalah sesuatu yang sering kali tidak dapat disentuh atau tidak dapat diraba. Jasa sesuatu yang berhubungan dengan sesuatu secara fisik, seperti pesawat meja, kursi, dan peralatan lainnya. Hal ini biasa di temui pada agen perjalanan atau biro jasa, bukan terletak pada kursi meja yang berada di pesawat, tetapi lebih kepada nilai. Oleh karena itu jasa dan pelayanan terbaik yang menjadi penyebab khusus yang secara alami disediakan.

a. Tidak dapat disimpan (inability to inventory) Salah satu dari ciri khusus jasa adalah tidak dapat di simpan, seperti saat kita menggunakan jasa penginapan atau hotel, kita menginginkan untuk menginat setengah malam dan setengah nya lagi untuk hari berikutnya, tentunya konsumen akan dihitung menginap dua hari.

b. Produuksi dan konsumsi secara bersama, Jasa adalah sesuatu yang dilakukan bersama dengan produksi. Misalnya, Hotel, tempat praktek dokter, restoran, pengurusan asuransi.

c. Memasukinya lebih mudah. Mendirikan usaha dibidang jasa membutuhkan investasi yang lebih sedikit, mencari lokasi lebih mudah dan banyak tersedia, tidak membutuhkan teknologi tinggi.

d. Sangat dipengaruhi oleh faktor dari luar. Jasa sangat dipengaruhi oleh faktor dari luar seperti, peraturan pemerintahan dan kenaikan harga energi. Karakteristik jsaa pelayanan tersebut akan menentukan definisi kualitas jasa pelayanan dan modal kualitas jasa pelayanan. Mendefinisikan kualitas jasa pelayanan membutuhkan pengetahuan dari berbagai disiplin ilmu sperti pemasaran, pesikologi, dan strategi bisnis.

(Olsen dan Wyckoff, 1987) melakukan pengamatan atas jasa pelayanan dan mendefinisikan jasa pelayanan adalah sekelompok manfaat yang berdaya guna baik 
secara eksplisit maupun inplisit atass kemudahan untuk mendapatkan barang maupun jasa pelayanan.

\section{8) Service Triangle}

Service triangle adalah suatu model interaktif manajemen pelayanan yang menghubungkan antara perusahaan dengan pelanggannya. Model tersebut terdiri dari tiga elemen dengan pelanggan sebagai titik fokus ( Albrecht and Zemke, dalam Budi W. Soetjipto, 1997), yaitu:

a. Strategi pelayanan (service stratgy)

Strategi pelayanan adalah strategi untuk memeberikan pelayanan kepada pelanggan dengan kualitass seebaik mungkin sesuai standar yang telah ditetapkan perusahaan.

$b$. Suberdaya manusia yang memberikan pelayanan (service people)

Orang yang berinteraksi langsung ataupun tidak berinteraksi secara langsung dengan pelanggan harus memberikan pelayanan kepada pelanggan secara tulus (empty), responsif, ramah, fokus dan menyadari bahwa kepuasan pelanggan adalah segalanya.

c. Sistem pelayanan (service system)

Sistem pelayanan adalah prosedur pelayanan kepada pelanggan yang melibatkan seluruh fasilitas fisik termasuk sumberdaya manusia yang dimiliki perusahaan. Sistem pelayanan harus dibuat secara sederhana, tidak berbelit-belit dan sesuai standar yang telah ditetapkan perusahaaan.

\section{9) Manajemen Kualitas ISO}

Usaha-usaha peningkatan dan pengendalian kualitas pada awalnya terbatas dalam lingkup pabrik (perusahaan) dan kemudiang berkembang ke luar pabri, dengan adanya perhatian terhadap pelanggan atau konsumen. Pengendalian kualitas oleh pabrik dan konsumen tersebut belum dianggap cukup,sehingga perlu pihak ketiga yang sifatnya independen.

Kehadiran pihak ketiga ini dianggap lebih objektif dan dapat memuaskan semua pihak. Sehingga munculah lembaga akreditasi yaitu ISO (Organization For Standardization).
Sistem manajement kualitas ISO didefinisikan sebagai standar sistem manajement kualitas yang mengelola proses pencapaian kualitas. Sistem manajement kualitas ISO-9000 mengatur hubungan antara suplier, perusahaan, dan konsumen. Oleh karena itu sistem manajement kualitas ISO sama sekali tidak berbicara tentang kualitas suatu produk, tetapi berbicara tentang proses pencapaian suatu tingkat kualitas tetentu. Hal ini mengisyaratkan bahwa perusahaan yang akan mengadopsi sistem manajemen kualitas ISO perlu menetepkan spesifikasi atau persyaratan karakteristik kualittas produk dan prosesnya.

\section{0) Pengertian Kepuasan Pelanggan}

Kata pelanggan adalah istilah yang akrab dengan dunia bisnis, secara tradisional pelanggan diartikan orang yang membeli dan menggunakan prouk. Dalam perusahaan yang bergerak dalam bidang jasa, pelanggan adalah orang yang menggunkan jasa pelayanan. Produk atau jasa yang berkualitas kalau tidak dapat menciptakan dan mempertahankan pelanggan. Mempertahankan pelanggan berarti mengharapkan planggan melakukan pembelian ulang atas produk dan jasa pada saat kebutuhan yang sama muncul di kemudian hari. Jika dilihat dari frequensi pembelian, produk dan jasa yang dibutuhkan konsumen banyak yang dibeli sekali saja (on time purchased), dibeli beberapa kali saja tetapi jarang (infrequently purchased product) dan sering dibeli (freequently purchased product).

Komsumen yang melakukan pembelian ulang atas produk dan jasa yang dihasilkan perusahaan adalah pelanggan dalam arti yang sebenarnya. Untuk menciptakan pembelian ulang sudah tentu perusahaan harus memberikan kepuasan kepada pelanggan. Hal ini menunjukan bahwa kepuasan pelanggan merupakan faktor kunci bagi konsumen dalam melakukan pembelian ulang.

\section{1) Pengertian Personal Selling}

Personal Selling adalah seseorang yang melakukan komunikasi tatap muka antara penjual dan pelangan untuk memperkenalkan suatu produk kepada calon pelanggan dan membentuk pemahaman pelanggan terhadap 
produk. Sehingga pelanggan akan memenuhi keinginan komunikator. Menurut Winardi (2001) Personal selling merupakan tendangan paling dekat dengan gawang yang sangat menentukan keseluruhan proses promosi.

Winardi (2001) mendefinisikan personal selling sebagai: interaksi antara pribadi dan secara tatap muka untuk mencapai tujuan menciptakan, memodifikasi, dan mengeksploitasi atau mengusahakan timbulnya suatu hubungan perukaran yang saling menguntungkan dengan pihak lain. Sementara itu swastha dan irawan (2000) mengemukakan pendapatnya bahwa: personal selling merupakan presentasi secara lisan dalam suatu percakapan dengan satu atau lebih calon pembelinya yang ditujukan untuk menciptakan penjualan.

\section{2) Prinsip-Prinsip Penjualan Personal Selling}

Kotler (2003) membagi menjadi tiga prinsip utama penjualan personal selling yaitu profesionalisme, keterampilan negosiasi, dan relationship marketing. Prinsip atau aspek pertama yang perlu diperhatikan dalam penjualan personal selling adalah profesionalisme. Globalisasi dan persaingan menuntut setiap salesperson untuk meningkatkan profesionalisme di bidangnya. Beberapa perusahaan cukup perhatian untuk meningkatkan profesionalisme salespersonnya melalui training mengenai seni menjual dengan anggaran yang cukup tinggi. Seorang salesprson tidak hanya dituntut untuk menjadi penerima pesanan yang pasip tetapi menjadi pencari pesanan yang aktif.

Ada dua pendekatan dalam program training untuk mengubah salesperson menjadi pencari pesanan yang aktif yaitu sales oriented appoach dan coustomer oriented approach. Pendekatan pertama melatih salespersone untuk melakukan teknik-teknik penjualan bertekanan tinggi/high preassure selling techniques. Sedangkan pendekatan yang berorientasikan pelanggan/customer memberikan pelatihan kepada salesperson bagaimana cara memecahkan masalahmasalah yang dihadapi oleh pelanggan. Pendekatan ini fokus pada keahlian salesperson untuk menganalisis kebutuhan pelanggan. Tidak ada pendekatan yang terbaik dalam segala situasi, tetapi pada umumnya program training salesperson diarahkan pada langkah-langkah utama dalam proses penjualan yang efektif.

Adapun langkah-langkah untuk melakukan penjualan efektif adalah:

a. Mengidentifikasi calon pelanggan dan kualifikasinya

b. Melakukan pendekatan awal/preapproach, untuk mengetahui kebutuhan, keinginan, siapa yang mengambil keputusan pembelian, karakteristik konsumen, dan gaya pembeliannya.

c. Melakukan pendekatan kepada calon pelanggan, untuk membina hubungan awal yang baik dengan mereka.

d. Presentai dan demonsatrasi yaitu, sales person memberikan penjelasan tentang keunggulan atau keistimewaan produk kepada konsumen

e. Mengatasi penolakan pelanggan

f. Menutup penjualan/closing

g. Follow up dan pemeliharaan, untuk mengetahui kepuasan pelanggan dan kelanjutan bisnisnya.

\section{3) Sifat-Sifat Personal Selling}

Sebagai personal selling harus memiliki kredibilitas yang tinggi dalam mempengaruhi pelanggan berikut sifat-sifat yang harus dimiliki oleh personal selling

a. Personal confrontation, yaitu adanya hubungan yang hidup langsung dalam proses komunikasi dan interaktif antara dua orang atau lebih.

b. Cultivation, yaitu sifat yang memungkinkan berkembangnya segala macam hubungan setelah terjadinya proses jual beli, seperti menjalin hubungan baik.

c. Response yaitu, situasi yang seolah-olah mengharuskan pelanggan untuk mendengar, memperhatikan, dan menanggapi.

Menurut Machfoedz (2010) wiraniaga perlu melakukan tahapan-tahapan penting sebagai berikut:
a. Prospekting, adalah orang yang mempunyai kemampuan untuk membeli.
b. Perencanaan pra-penjualan, personal 
selling dapat mengukur potensi serta kemampuan diri dan mengetahui segala bentuk produk jasa yang akan dijual kepada konsumen.

c. Presentasi penjualan, personal selling menguraikan penjelasan tentang fungsi dan manfaat produk.

d. Mengatasi keberatan prospek, keberatan yang dikemukakan oleh prospek merupakan pernyataan ketidak bersediaannya untuk membeli produk yang ditawarkan oleh personal selling.

e. Menutup penjualan, adalah proses untuk membantu prospek dalam

f. mengambil keputusan yang mendatangkan manfaat bagi mereka.

\section{METODE PENELITIAN}

Penilitian ini menggunakan metode Deskriptif kualitatif, yaitu menurut Bogdan dan Taylor, mengatakan bahwa "Metodologi kualitatif merupakan prosedur penelitian yang menghasilkan data deskriptif berupa kata-kata tertulis atau lisan dari orang-orang atau perilaku yang diamati. Pendektannya diarahkan pada latar dan individu secara holistik atau utuh (dalam Melong, 2002:3)

Tujuan penelitian Deskriptif adalah menggambarkan karakteristik atau perilaku suatu populasi dengan cara yang sistematis dan akurat. Teknik pengumpulan data yang dugunakan: analisis data, wawancara, observasi, dokumentasi, studi pustaka.

\section{HASIL DAN PEMBAHASAN \\ 1) Peranan Personal Selling dalam Jasa Informasi dan Pelayanan}

Unit Jasa Informasi dan Pelayanan Pusat Konservasi Tumbuhan Kebun Raya Bogor dinaungi oleh Sub Bagian Jasa dan Informasi yang bergerak dalam bidang kehumasan. Unit Jasa Informasi dan Pelayanan dibentuk untuk mengoptimalkan kinerja bidang kehumasan dalam melayani masyarakat karena tingginya minat masyarakat dalam melakukan kegiatan di Kebun Raya Bogor. Orang yang bertugas untuk melakukan penjualan jasa biasa disebut dengan personal selling. Personal selling juga berperan dalam membangun citra Kebun Raya Bogor.

Personal selling adalah orang yang menyampaikan informasi kepada konsumen dengan cara membujuk konsumen agar memiliki ketertarikan dengan produk yang ditawarkan. Personal selling yang bertugas di Jasa Informasi dan Pelayanan berperan untuk menjual produk berupa jasa kepada konsumen dengan cara memberikan penjelasan dengan sebuah brosur yang berisi tentang peta lokasi dan daftar harga yang disewakan. Saat kegiatan penjualan berlangsung personal selling juga tidak enggan untuk memberikan saran dan masukan jika ada hal-hal yang konsumen butuhkan untuk kelangsungan kegiatan konsumen.

Pusat Konservasi Tumbuhan Kebun Raya Bogor menawarkan berbagai macam bentuk jasa yang dapat digunakan oleh konsumen. Jasa yang ditawarkan seperti penyewaan gedung, penggunaan lokasi, dan pelayanan dalam bentuk pendidikan.

Jasa merupakan produk yang bukan berupa barang namun dapat memenuhi kebutuhan konsumen dan memberikan kepuasan bagi konsumen. Menurut (Swasta, 1996) jasa adalah barang yang tidak kentara (intangible product) yang dibeli dan dijual di pasar melalui suatu transaksi pertukaran yang saling memuaskan.

Klasifikasi yang harus dimiliki oleh personal selling di Kebun Raya Bogor dalam memasarkan jasa adalah memiliki kemampuan untuk melakukan pendekatan dengan konsumen. Personal selling harus terlihat meyakinkan dan percayadiri dalam mempresentasikan produk, agar konsumen yakin bahwa produk yang ditawarkan akan memberikan kepuasan. Saat melakukan presentasi produk kepada konsumen personal selling tidak memaksa konsumen untuk selalu membeli produk, personal selling hanya memberikan penawaran atas apa yang dibutuhkan konsumen.

Peranan personal selling sangat dibutuhkan bagi perusahaan dalam membangun hubungan dengan konsumen, agar produk yang ditawarkan dapat dikenal luas oleh masyarakat. Tugas personal selling dalam kegiatan pemasaran ialah untuk mengajak konsumen baru bergabung menggunakan produk dan mempertahankan kualitas hubungan dengan konsumen yang telah lama berlangganan. Seperti pada kegiatan pelayanan 
pelanggan tahunan yang dari tahun ke tahun pegguna kartu keanggotaan atau member terus memperpanjang masa keaktifan kartu. Hal ini menjadi salah satu bentuk kelebihan personal selling dalam membangun hubungan baik dengan konsumennya.

Kelemahan utama yang dimiliki personal selling dalam sebuah perusahaan adalah mahalnya biaya untuk membayar sewa personal selling. Untuk mengatasi hal ini Kebun Raya Bogor menggunakan pegawai terpilih di Kebun Raya Bogor, untuk menjadi staf personal selling. Biaya yang dikeluarkan untuk melakukan kegiatan penjualan jasa pun tidak banyak, karena personal selling hanya menunggu konsumen datang dan lokasi yang digunakan pun tidak berpindah- pindah. Personal selling yang menangani konsumen di Jasa Informasi dan Pelayanan sangat terbatas, sehingga konsumen harus menunggu giliran untuk melakukan penyewaan. Sempitnya ruang pelayanan jasa dan fasilitas merupakan salah satu kendala yang mengakibatkan konsumen harus menunggu giliran. Prinsip yang dipegang oleh personal selling di Jasa Informasi dan Pelayanan,yaitu akan tetap berusaha mematuhi peraturan yang ditetapkan oleh pihak internal. Contohnya dalam memberikan keringanan harga atau diskon, personal selling akan memberikan sesuai dengan kebijakan yang ada di Kebun Raya Bogor.

Personal selling merupakan alat yang dianggap paling efektif pada tahap proses promosi dan pembelian lebih lanjut di Kebun Raya Bogor. Jasa Informasi dan Pelayanan tidak melakukan promosi dalam hal lain seperti iklan televisi, radio dan media massa. Merurut Winardi (1992) Personal selling merupakan tendangan paling dekat dengan gawang yang sangat menentukan keseluruhan proses promosi. Kebun Raya Bogor mempercayakan seluruh kegiatan pelayanan masyarakat kepada kinerja personal selling dalam melakukan pemasaran dan promosi kepada konsumennya.

Menurut Machfoedz (2010) terdapat bauran komunikasi pemasaran yang terdiri atas bauran khusus antara lain:

a. Periklanan merupakan setiap bentuk presentasi yang dikemukakan secara tidak langsung (tanpa personil) dan promosi ide, barang atau jasa yang dilakukan oleh sponsor tertentu.

b. Personal Selling presentasi langsung yang dilakukan oleh personil wiraniaga perusahaan dengan tujuan menjual dan menjalin hubungn dengan konsumen.

c. Promosi Penjualan motivasi jangka pendek untuk mendorong pembelian atau penjualan suatu produk atau jasa.

d. Hubungan Masyarakat (public relations) membangun hubungan baik dengan berbagai publik perusahaan dengan tujuan mendapatkan publisitas yang luas, membangun citra positif perusahaan, dan mengatasi gossip, laporan, serta berbagai event yang dapat merugikan perusahaan.

Kegiatan bauran komunikasi yang dilakukan di Kebun Raya Bogor, belum sepenuhnya dilakukan dengan apa yang dikemukakan oleh Machfoedz. Periklanan tidak dilakukan pada kegiatan penjualan jasa, personal selling hanya memberikan brosur sebagai media promosi langsung. Pada kegiatan promosi penjualan jangka pendek juga belum terrealisasikan di Kebun Raya Bogor, adapun kegiatan promosi jangka panjang yaitu potongan harga tiket masuk bagi kegiatan rombongan. Kegiatan yang sudah dilakukan dalam kegiatan promosi untuk memasarkan jasa tentunya kegiatan presentasi yang dilakukan oleh personal selling.

Peran humas pun sangat mendorong kegiatan penjualan jasa yang dilakukan oleh personal selling. Kinerja humas dalam membangun hubungan baik dengan perusahaan dan masyarakat luas menjadi sebuah kepercayaan masyarakat untuk melakukan kegiatan di Kebun Raya Bogor.

Menurut Machfoedz (2010) strategi promosi terbagi menjadi dua yaitu strategi mendorong (push strategi) dan strategi menarik (pull strategi). Strategi mendorong yaitu strategi yang memerlukan pemanfaatan tenaga penjualan dan promosi perdagangan untuk mendorong produksi melalui anggota saluran distribusi ke arah konsumen akhir, sedangkan strategi menarik adalah diarahkan oleh produsen dalam bentuk periklanan dan promosi konsumen. Jika strategi ini berhasil 
dengan efektif, permintaan produk dari konsumen akan meningkat dan menambah pendapatan bagi perusahaan. Strategi promosi yang digunakan oleh personal selling dalam Jasa Informasi dan Pelayanan adalah strategi mendorong (push strategy). Hal tersebut merupakan bagian dari kelebihan personal selling dalam memasarkan produk yang juga dapat melakukan promosi yang efektif karena dilakukan secara langsung berhadapan dengan konsumen.

\section{2) Kegiatan komunikasi Personal Selling dalam Penjualan Jasa}

Komunikasi merupakan hal terpenting untuk kelangsungan kegiatan yang dilakukan oleh personal selling dalam kegiatan pemasaran. Menurut (Pearson dan Nelson) dalam Mulyanan dan Rahmat (2005) mengemukakan bahwa komunikasi mempunyai dua fungsi umum.

Pertama untuk kelangsungan hidup diri sendiri yang meliputi keselamatan fisik, meningkatkan kesadaran pribadi, menampilkan diri kita sendiri kepada orang lain dan mencapai ambisi pribadi. Kedua, untuk kelangsungan hidup masyarakat, tepatnya untuk memperbaiki hubungan sosial dan mengembangkan keberadaan suatu masyarakat.

Komunikasi merupakan modal utama bagi personal selling untuk melakukan peran dan fungsinya. Personal selling dalam melakukan kegiatan penjualan jasa selalu dilakukan dengan komunikasi interpersonal. Menurut (Tubbs, 1974) Komunikasi interpersonal merupakan komunikasi yang berlangsung antara dua orang, Secara tatap muka dan dalam suasana pribadi.

Alur komunikasi yang dilakukan oleh personal selling di Jasa Informasi dan Pelayanan memiliki alur yang beragam. Alur komunikasi ke atas yang dilakukan kepada kepala Kebun Raya Bogor, saat personal selling melakukan Laporan Pertanggung Jawaban kegiatan bulanan. Alur komunikasi ke samping yang dilakukan kepada staf pegawai lain seperti dalam kegiatan menyerahkan surat masuk yaitu surat permohonan magang, penelitian yang akan diproses oleh staf yang menangani surat balasan. Alur komunikasi kebawah dilakukan rutin oleh personal selling kepada petugas loket dan petugas keamanan.

Dalam pembuatan kwitansi untuk kegiatan di Jasa Informasi dan Pelayanan dibuat oleh petugas loket. Setiap harinya personal selling juga berhubungan langsung dengan petugas keamanan untuk penertiban kegiatan, dengan memberikan informasi seperti berapa banyak kegiatan yang dilakukan di lapangan pada hari itu.

Komunikasi yang dilakukan oleh personal selling dengan konsumen menjadi tujuan utama personal selling di Jasa Informasi dan Pelayanan. Komunikasi yang dapat dilakukan dengan dua cara yaitu komunikasi tatap muka dan komunikasi bermedia. Komunikasi tatap muka dilakukan secara langsung yaitu bertemunya kontak pribadi antara personal selling dan konsumen. Komunikasi bermedia yaitu dilakukan dengan menggunakan alat sebagai perantaranya seperti telepon dan fax.

Komunikasi yang terjadi di lapangan dengan konsumen sama halnya dengan komunikasi yang dilakukan kepada kerabat dan sahabat, namun lebih menjurus kepada kegiatan penjualan jasa dan promosi. Sereno dan Bodaken (1975) komunikasi interpersonal hakekatnya adalah proses melalui mana seseorang membangun, memelihara, dan mengakhiri, hubungannya dengan orang lain.

Komunikasi dalam konteks hubungan antarpribadi ini relatif tidak berstruktur dan informal yang diikat secara tatap muka dan merupakan sebuah proses transaksi yang berlangsung simultan. Dapat diartikan ketika ada dua orang yang berkomunikasi pada level antarpribadi, mereka akan bergantian berbicara seperti pada halnya personal selling dan konsumen satu memberikan penawaran dan promosi dan lainnya memberikan tanggapan dan tindakan.

Kegiatan ini dikatakan bukan saja sebagai interaksi juga sebagai transaksi yang dipengaruhi oleh sistem yaitu pemasaran produk berupa jasa. Komunikasi yang dilakukan secara langsung dapat membujuk konsumen lebih baik dari mengkomunikasikan produk melalui media.

Personal selling dapat mengetahui bagaimana membujuk konsumen dan mengetahui sikap 
dari konsumen saat bertatap muka.

Komunikasi yang dilakukan melalui telepon hanya dapat memberikan informasi secara singkat, namun tetap membujuk konsumen dalam penjualan jasa. Hal tersebut dikarenakan informasi yang diberikan cukup rumit dalam penjualan jasa, terdapat brosur dan peta lokasi yang harus dipahami oleh konsumen. Untuk memaksimalkan kegiatan ini personal selling biasanya mengirimkan brosur dan daftar harga melalui fax agar dalam memberikan informasi konsumen tidak kebingungan.

Komunikasi melalui telepon tetap banyak diminati oleh konsumen, dengan kelebihannya yaitu memudahkan konsumen dalam menghemat waktu dan biaya. Kegiatan penelepon dapat juga dilakukan untuk pemesanan tempat dan tanggal pelaksanaan kegiatan, namun konsumen tidak bisa melakukan transaksi penjualan melalui telepon.

Kegiatan yang dilakukan personal selling dalam melakukan penjualan jasa secara tatap muka, dianggap memiliki alur komunikasi yang teratur dan efektif dibandingkan dengan bermedia. Tujuan dasar organisasi penjualan dalam perusahaan adalah melakukan penjualan yang menguntungkan atas nama perusahaan, maka personal selling lebih memprioritaskan konsumen untuk melakukan komunikasi secara langsung. Strategi dan rencana penjualan diimplementasikan untuk membantu tercapainya tujuan penjualan di Kebun Raya Bogor.

Menurut Machfoedz (2010) wiraniaga perlu melakukan tahapan-tahapan penting sebagai berikut:

a. Prospekting, adalah orang yang mempunyai kemampuan untuk membeli.

b. Perencanaan pra-penjualan, personal selling dapat mengukur potensi serta kemampuan diri dan mengetahui segala bentuk produk jasa yang akan dijual kepada konsumen.

c. Presentasi penjualan, personal selling menguraikan penjelasan tentang fungsi dan manfaat produk.

d. Mengatasi keberatan prospek, keberatan yang dikemukakan oleh prospek merupakan pernyataan ketidak bersediaannya untuk membeli produk yang ditawarkan oleh personal selling.

e. Menutup penjualan, adalah proses untuk membantu prospek dalam mengambil keputusan yang mendatangkan manfaat bagi mereka.

Teori diatas juga diaplikasikan oleh personal selling di PKT-Kebun Raya Bogor. Tahapan proses penjualan jasa dan fasilitas yang dilakukan, yaitu:

a. Menyambut konsumen, kegiatan ini merupakan awal penjualan. Pada pembukaan penjualan personal selling harus memberikan kesan pertama yang baik kepada konsumen agar kegiatan penjualan mencapai tujuan akhir.

b. Menanyakan identitas dan keperluan konsumen. Kegiatan menyambut konsumen diikuti dengan pengetahuan personal selling terhadap konsumen.

Seperti identitas diri dan apa yang dibutuhkan konsumen. Hal ini dibutuhkan agar personal selling memiliki sedikit gambaran untuk melakukan tahapan penjualan selanjutnya.

c. Memberikan informasi yang dibutuhkan konsumen. Personal selling akan memberikan informasi yang dengan memberikan sebuah brosur yang sesuai dengan kegiatan permintaan konsumen.

d. Memberikan penjelasan mengenai peraturan yang berlaku di Kebun Raya Bogor. Hal ini dilakukan untuk menciptakan kegiatan yang aman dan nyaman bagi konsumen dan pihak internal. Salah satu peraturan tersebut adalah tidak membuang sampah dan menjaga fasilitas dilingkungan Kebun Raya Bogor serta mengarahkan lokasi parkir.

e. Adanya kesepakatan dari konsumen. Jika konsumen sudah menyetujui, personal selling akan memberikan formulir diantaranya terdapat formulir identitas yang berisikan tentang data diri dan jenis kegiatan. Formulir lainnya adalah ISO atau penyerahan produk adalah formulir yang berfungsi sebagai dokumen untuk mengetahui bahwa produk yang dijual sudah diterima oleh konsumen.

f. Melakukan pembayaran di loket. Pada tahapan akhir dimana konsumen sudah 
mengisi beberapa formulir untuk menyetujui penjualan jasa, selanjutnya personal selling akan membuatkan kwitansi pembayaran di loket.

g. Komunikasi menjadi sangat penting bagi sebuah perusahaan dalam penjualan jasa, dibutuhkan ketelitian dan hubungan yang harmonis antara perusahaan dan konsumen. Hal ini dilakukan karena untuk mencapai kesepakatan yang menguntungkan bagi dua belah pihak. Kegiatan penjualan jasa ini tentunya membutuhkan komunikasi yang efektif untuk dapat mencapai tujuan tersebut.

\section{3) Peranan Personal Selling dalam Kegiatan Pemasaran Jasa}

Unit Jasa Informasi dan Pelayanan dibentuk karena banyak permintaan pengunjung yang ingin melakukan kegiatan di Kebun Raya Bogor. Untuk mengoptimalkan tujuan Kebun Raya Bogor dalam menghindari kerusakan fasilitas dari orang-orang tidak bertanggung jawab, maka dibentuklah Jasa Informasi dan Pelayanan. Jasa Informasi dan Pelayanan juga dibentuk karena pernah terjadi kegiatan komersil yang tidak diketahui oleh pihak internal, oleh karena itu Kebun Raya Bogor khawatir jika kegiatan yang dilakukan akan mencoreng nama baik LIPI. Jasa Informasi dan Pelayanan berupaya dalam memberikan kepuasan kepada masyarakat dan mengarahkan kegiatan yang aman dan nyaman bagi kedua belah pihak.

Menurut Machfoedz (2010) Komunikasi pemasaran merupakan usaha menyampaikan pesan kepada publik terutama konsumen sasaran mengenai keberadaan produk di pasar. Komunikasi pemasaran yang terencana akan menentukan arah dan cara untuk mencapai tujuan pelaksanaan personal selling baik bagi perusahaan maupun konsumen untuk mendapatkan kesepakatan dan kepuasan satu sama lain.

Personal selling bertanggung jawab untuk memberikan pelayanan berupa jasa dan informasi yang ada di Pusat Konservasi Tumbuhan Kebun Raya Bogor.

Produk jasa yang ditawarkan oleh personal selling diantaranya, penyewaan area dan fasilitas, pemotretan dan shooting, pelanggan tahunan, wisata flora, promosi. Kegiatan yang dilakukan personal selling lainnya adalah memberikan informasi seperti potongan harga tiket masuk, pembukaan pintu, parkir kendaraan, perizinan ke Istana Bogor, dan informasi lainnya mengenai Kebun Raya Bogor.

Bauran pemasaran atau bisa disebut 4P Menurut Payne (2000) bila dikaitkan dengan elemen marketing mix yang diterapkan oleh Pusat Konservasi Tumbuhan Kebun Raya Bogor:

a. Produk adalah barang atau jasa yang ditawarkan perusahaan kepada pasar sasaran. Produk yang dijual oleh Pusat Konservasi Tumbuhan Kebun Raya Bogor berbentuk jasa. Jasa layanan yang bisa dinikmati di Pusat Konservasi Tumbuhan Kebun Raya Bogor yaitu sewa fasilitas area, izin pemotretan dan shooting, permohonan keanggotaan, wisata flora, dan promosi.

b. Harga (price) adalah sejumlah uang yang harus dibayar oleh konsumen untuk mendapatkan produk. Harga (price) yang diberikan sesuai dengan Peraturan Pemerintah No. 75 tahun 2007. Peraturan tersebut mengatur kisaran harga yang dibebankan kepada konsumen atas bentuk layanan yang ingin dinikmati. Tetapi untuk sewa fasilitas seperti tenda, kursi, panggung, dan lainnya harga ditentukan oleh koperasi Pusat Konservasi Tumbuhan Kebun Raya Bogor.

c. Tempat (Place) adalah berbagai kegiatan yang membuat produk terjangkau

d. Oleh konsumen sasaran. Tempat distribusi (Place) untuk memasarkan produk Pusat Konservasi Tumbuhan Kebun Raya Bogor hanya dilakukan di lingkungan Kebun Raya Bogor.

e. Promosi adalah kegiatan yang dilakukan oleh perusahaan untuk menonjolkan

f. keistimewaan produknya. Promosi yang dilakukan dalam meningkatkan penjualan jasa tidak banyak yang dilakukan oleh Jasa Informasi dan Pelayanan. Bentuk promosi jangka panjang yang dilakukan terdapat pada potongan harga tiket masuk bagi kegiatan rombongan. 


\section{1) Pelayanan Sewa Area dan Fasilitas}

Beberapa area dan fasilitas yang bisa dinikmati dan disewakan kepada pengunjung adalah penyewaan lokasi atau lapangan yang terbagi menjadi empat area utama, diantaranya:

a. Area satu yaitu halaman Guest House Nusa Indah.

b. Area dua yaitu Lapangan depan Cafe de' daunan.

c. Area tiga yaitu Lapangan Randu/Strophanthus.

d. Area empat lapangan Astrid

Lokasi satu yaitu halaman Guest house yang biasanya digunakan untuk kegiatan acara resmi. Lokasi dua yaitu Cafe de' daunan, lokasi ini berkapasitas kurang lebih 3000 orang. Lokasi dua ini memiliki kelebihan yaitu lokasi merupakan lapangan luas dengan pemandangan berada depan cafe de' daunan.

Kekurangan pada lokasi dua ini yaitu terik matahari akan langsung memantulkan pada kegiatan yang berlangsung. Lokasi dua ini biasanya digunakan untuk acara pernikahan dan acara-acara besar. Jika konsumen menginginkan lokasi yang teduh maka ada solusi yang akan personal selling berikan yaitu menempatkan konsumen di lokasi tiga dan empat.

Lokasi ini juga dapat menampung ribuan orang, kelebihan pada lokasi tiga dan empat yaitu dapat dibagi menjadi beberapa lokasi. Lokasi 3 itu diantaranya kupel, randu tengah dan pohon tumbang, sedangkan lokasi empat dibagi menjadi dua bagian yaitu lapangan astrid dan segitiga dekat masjid. Lokasi ini diberi nama sesuai dengan ciri tempat tersebut untuk membedakan agar konsumen tidak merasa kebingungan.

Personal selling akan mengecek agenda kegiatan bila konsumen sudah menentukan tanggal diselenggarakannya acara, agar tidak ada kegiatan yang bersamaan dengan konsumen lain. Kegiatan yang diselenggarakan juga dapat ditunjang dengan penyediaan beberapa fasilitas.

Personal selling akan menawarkan fasilitas yang bisa disewa oleh konsumen diantaranya, panggung, tenda, organ tunggal, terpal, kursi, meja, dan sound system. Personal selling juga melayani pembayaran untuk sewa area dan fasilitas secara langsung.
Setelah konsumen menentukan lokasi area, tanggal pelaksanaan serta fasilitas yang akan digunakan, personal selling akan memberikan formulir identitas dan formulir ISO kepada konsumen sebagai data pembuatan kwitansi. Formulir identitas berisi tentang data diri konsumen dan jasa yang digunakan oleh konsumen, ISO atau bisa disebut juga dengan formulir penyerahan produk sebagai tanda bahwa produk yang beli oleh konsumen sudah diterima dengan baik.

Penyerahan produk ini seharusnya ditandatangani saat kegiatan sudah dilaksanakan, namun pada kenyataanya konsumen menginginkan diawal pembelian jasa agar tidak merepotkan konsumen. Personal selling tidak menerima pembayaran dalam bentuk transfer, maka pembayaran harus dilakukan di muka.

Kegiatan penyewaan area dan fasilitas serta kegiatan promosi diberikan jangka waktu satu minggu sebelum acara berlangsung untuk melakukan pelunasan, berbeda halnya dengan kegiatan yang lain seperti pemotretan dapat dilakukan pada saat kegiatan akan berlangsung. Kegiatan dalam sewa area dan fasilitas adalah kegiatan yang dianggap cukup memakan banyak waktu dibanding dengan kegiatan penjualan jasa lainnya. Komunikasi tatap muka adalah cara yang paling efektif dilakukan pada penjualan jasa, hal ini dilakukan untuk menghindari kesalahan fahaman konsumen mengenai lokasi dan berapa banyak peralatan yang akan digunakan. Komunikasi yang dilakukan dengan tatap muka tentunya akan menimbulkan kontak pribadi yaitu feedback, sehingga kedua belah pihak dapat saling melontarkan pertanyaan. Komunikasi tatap muka juga dapat mempermudah personal selling untuk mengubah pendapat dan perilaku konsumen dalam hal sikap (attitude), pendapat (opinion), perubahan perilaku (behavior). Kegiatan komunikasi secara langsung yang terjadi dilapangan seperti saat konsumen datang untuk menyewa beberapa area dan fasilitas, maka personal selling akan memberikan apa yang konsumen butuhkan.

Personal selling juga akan membantu konsumen dalam memberikan pilihan fasilitas dan area yang terbaik sehingga konsumen juga akan tertarik dengan penawaran-penawaran 
yang diberikan oleh personal selling. Komunikasi yang dilakukan secara tatap muka dapat merubah sikap konsumen, yang tidak suka menjadi suka dengan penjelasan yang mendalam dari personal selling.

\section{2) Pelayanan Pelanggan Tahunan}

Kegiatan pelayanan tahunan (member) terdiri dari dua ketegori, yaitu lanjut usia (lansia) dan biasa. Lansia dikenakan biaya lebih ringan untuk menjadi anggota dibandingkan dengan anggota biasa. Keanggotaan juga terdiri dari dua jenis, yaitu anggota pejalan kaki dan pengguna mobil pribadi, anggota dengan kendaraan dikenakan biaya tambahan. Batas waktu kartu anggota ini adalah selama satu tahun, konsumen dapat memperpanjang dengan mengganti kartu anggota yang baru.

a. Usia >60th Rp. 300.000,-

b. Usia <60th Rp. 500.000,-

c. Kendaraan Rp. 500.000,-

Pemohon yang ingin menjadi anggota terlebih dahulu harus menyerahkan foto berwarna ukuran 4x6 dan mengisi formulir keanggotaan. Formulir keanggotaan berbeda dengan formulir penyewaan area dan kegiatan lainnya, ISO atau penyerahan produk dalam pelayanan keanggotaan akan diberikan setelah kartu anggota diberikan kepada konsumen.

Dalam pembuatan kartu keanggotaan dibutuhkan waktu satu minggu, karena pembuatan kartu ini dikerjakan oleh pihak Unit Dokumentasi dan Informasi. Kegiatan keanggotaan ini sering juga mendapatkan kendala, pemohon terkadang mewakilkan permohonan kepada perwakilannya. Personal selling memperbolehkan pendaftaran diwakilkan dengan syarat menyerahkan fotocopy KTP dari pemohon. Dalam pengisian formulir dapat diisi dan ditandatangani oleh wakil pemohon.

Selama pengamatan berlangsung, pemohon lebih banyak yang ingin melanjutkan masa keanggotaan. Pemohon terdiri dari lansia yang biasa menggunakan keanggotan untuk menikmati fasilitas Kebun Raya Bogor. Fasilitas ini disarankan bagi pengunjung ingin melakukan olahraga dengan udara yang sejuk.

Fasilitas yang diberikan bagi keanggotaan adalah anggota diizinkan masuk sebelum jam oprasional Kebun Raya Bogor dan kegiatan keanggotaan tahunan ini tentunya jauh lebih menguntungkan dibanding dengan harus membeli tiket masuk. Adapun peraturan yang berlaku pada kartu keanggotaan ini, yaitu hanya pemilik kartu keanggotaan saja yang dapat menggunakannya.

\section{3) Pelayanan Shooting dan Pemotretan}

Bentuk pelayanan lainnya yang diberikan adalah layanan untuk mendapatkan izin shooting dan pemotretan, baik komersil maupun non-komersil. Pemohon yang akan melakukan shooting, diharuskan memberikan surat yang akan diproses oleh personal selling. Personal selling harus melihat terlebih dahulu kegiatan yang dilakukan pemohon apakah sesuai dengan peraturan atau tidak, personal selling tidak mengizinkan kegiatan yang nantinya akan merugikan nama baik Kebun Raya Bogor.

Personal selling juga mengalami beberapa kendala saat proses shooting dilakukan, seperti waktu shooting yang akan dilakukan pemohon. Personal selling tidak bisa mengizinkan konsumen untuk meminta waktu yang tidak sesuai dengan jam operasional Kebun Raya Bogor. Konsumen harus mematuhi peraturan yang berlaku di Kebun Raya Bogor, hal ini dilakukan personal selling untuk mendisiplinkan setiap kegiatan yang akan dilangsungkan.

Kegiatan lainnya yaitu pelayanan pemotretan, kegiatan ini juga dapat dilakukan di Kebun Raya Bogor. Konsumen yang akan melakukan pemotretan non-komersil tidak perlu mengajukan surat sebelum pelaksanaan kegiatan. Hal ini diizinkan karena pemotretan non-komersil tidak untuk dipublikasikan. Konsumen dapat langsung melakukan pembayaran jasa pemotretan pada saat itu juga.

Personal selling dituntut untuk melakukan pelayanan secara cepat dan tepat, hal ini dilakukan agar pemohon dapat merasa puas dengan pelayanan personal selling untuk mengefektifkan waktu konsumen. Sedangkan untuk pemotretan komersial konsumen diharuskan mengajukan surat untuk mendapatkan izin. Pemotretan komersial ditangani langsung oleh pengawas personal selling. Hal ini dilakukan agar personal selling 
dapat mengetahui tujuan pemotretan. Berikut adalah daftar tarif untuk kegiatan shooting dan pemotretan.

\section{4) Pelayanan Promosi}

Pelayanan promosi adalah kegiatan yang dilakukan perusahaan komersil dalam penjualan produk berupa minuman atau makanan, untuk mempromosikan kepada pengunjung di Kebun Raya Bogor. Salah satu kegiatan yang dilakukan adalah produk minuman Mizone. Pihak dari perusahaan Mizone yang akan melakukan kegiatan promosi datang langsung menemui personal selling untuk melakukan permohonan membuka stand di Kebun Raya Bogor.

Lokasi yang akan digunakan telah ditentukan oleh personal selling, lokasi tersebut adalah pintu utama Kebun Raya Bogor dan di sekitar Taman Anggrek bagian dalam. Lokasi pertama yaitu pintu utama dipilih karena banyak dilalui oleh pengunjung, sehingga produk yang dijual dapat langsung terlihat oleh pengujung. Lokasi kedua yaitu Taman Anggrek dipilih karena lokasi ini jauh dari penjual makanan dan minuman, pengunjung yang berjalan kaki dari pintu utama pasti akan merasa lelah sehingga pengunjung mudah menjangkau stand tersebut. Kegiatan promosi ini dikenakan tarif bagi perusahaan sebesar Rp. 1.000.000,-/hari.

\section{5) Pelayanan Wisata Flora}

Paket wisata flora merupakan salah satu program wisata yang bersifat edukasi, program ini ditujukan kepada anak sekolah (SD, SMP, SMA). Paket wisata flora diisi dengan materi mengenai Kebun Raya Bogor serta hal yang berhubungan dengan tumbuhan baik secara taksonomi maupun fungsi. Peserta juga dibekali pengetahuan mengenai proses tumbuhnya bunga Amorpopalus titanium yang terdapat di Kebun Raya Bogor. Setiap anak akan diberikan bibit tanaman yang telah mereka tanam saat melakukan kegiatan wisata flora.

Tugas personal selling dalam kegiatan wisata flora hanya dalam melakukan pemasaran, yaitu memberikan informasi dan mengatur waktu kunjungan. Kegiatan wisata flora akan dipandu oleh divisi yang sudah dibentuk untuk membimbing peserta wisata flora. Konsumen yang ingin mengetahui informasi mengenai paket wisata ini bisa bertanya kepada personal selling baik melalui tatap muka maupun telepon. Konsumen biasanya menanyakan mengenai isi dari paket wisata serta biaya yang dikenakan bagi peserta. Informasi mengenai potongan harga juga banyak ditanyakn oleh konsumen, dalam hal ini potongan harga tidak berlaku karena kegiatan ini merupakan paket dan banyak fasilitas yang akan didapatkan oleh peserta.

Kegiatan ini dilakukan dengan batas minimal 30 peserta, biaya yang harus dikeluarkan dalam kegiatan paket edukasi ini adalah Rp.20.000/anak. Kegiatan wisata flora dapat berlangsung jika pihak yang bertanggung jawab sebelumnya mengirimkan surat atau fax untuk menentukan tanggal pelaksanaan. Petugas yang menangani kegiatan wisata flora hanya dapat menangani satu rombongan, tidak bisa melakukan kegiatan dalam waktu yang bersamaan untuk itu personal selling harus mengatur jadwal setiap rombongan yang akan melakukan kegiatan wisata flora dengan baik

\section{6) Informasi Seputar Kebun Raya}

Kegiatan komunikasi interpersonal yang dilakukan oleh personal selling dengan media telepon dan fax memiliki keunikan tersendiri. Kegiatan komunikasi melalui telepon banyak datang dari berbagai daerah yang memiliki bahasa dengan budaya yang berbeda. Personal selling pun harus dapat memahami komunikasi yang dimiliki oleh budaya konsumen, agar konsumen bisa mendapatkan informasi yang dibutuhkan. Infomasi yang diberikan oleh personal selling yaitu seputar potongan tiket masuk, pembukaan pintu, tour guide, harga tiket, fasilitas, serta tiket kendaraan. Masyarakat Kota Bogor maupun di luar Kota Bogor yang ingin mengetahui informasi dapat langsung berkomunikasi dengan petugas personal selling melalui telepon.

Kebun Raya Bogor memberikan penawaran menarik yaitu diskon bagi rombongan. Syarat yang harus dipenuhi adalah, rombongan minimal terdiri dari 25 orang yang sebelumnya telah mengirimkan surat atau fax mengenai permohonan diskon. Potongan harga yang diberikan terdiri dari empat kategori antara lain anak yatim, anak sekolah, instansi pemerintahan, dan masyarakat umum. Permohonan potongan harga ini dilakukan dua hari sebelum 
rombongan melakukan kunjungan, personal selling akan mendata setiap surat dan jumlah rombongan yang akan melakukan kunjungan dan menyerahkan surat atau fax kepada bagian informasi.

Pada hari pelaksanaan kunjungan, petugas yang berada bagian informasi akan memberikan kartu diskon untuk diberikan ke loket agar mengetahui bahwa rombongan sudah mendapatkan potongan harga. Terdapat hal yang menarik pada kegiatan ini, banyak sekali pengunjung yang meminta potongan harga lebih dari yang telah ditentukan oleh Kebun Raya Bogor. Setiap harinya personal selling selalu menemui konsumen yang melakukan negosiasi dalam permintaan potongan harga.

Terlebih konsumen yang berasal dari instansi pemerintahan, tidak sedikit dari mereka yang meminta potongan harga mencapai $75 \%$ bahkan gratis. Untuk mengatasi hal ini personal selling tidak bisa memberikan kebijakan lebih, personal selling lebih berpihak pada peraturan internal yang sudah ditetapkan di Kebun Raya Bogor. Personal selling tetap bersikap profesional dalam memberikan keputusan, dengan memberikan penjelasan bahwa potongan harga yang telah ditetapkan tidak dapat dirubah karena hal ini merupakan keputusan kepala Kebun Raya Bogor.

Informasi yang dapat diberikan oleh personal selling juga mengenai pembukaan pintu. Kebun Raya Bogor memiliki empat pintu masuk yang tidak semuanya dapat dilalui oleh pengunjung, hal ini dilakukan karena penjaga loket berada di pintu utama kebun raya. Alasan keamanan juga menjadi salah satu faktor pintu tidak dibuka.

Mengenai jadwal pembukaan pintu utama dibuka setiap hari, sedangkan pintu yang lainnya dibuka hanya hari-hari tertentu seperti sabtu dan minggu itu pun hanya pintu dua dan empat. Permohonan pembukaan pintu biasanya berlangsung jika pengunjung akan melakukan kegiatan yang jauh dari pintu utama, maka persyaratannya adalah pemohon harus mengisi formulir permohonan pembukaan pintu untuk diserahkan kepada pihak yang berwenang di Kebun Raya Bogor.

Pengunjung yang datang dari luar Bogor biasanya meminta tour guide terlebih bagi wisatawan asing yang ingin mengetahui mengenai Kebun Raya Bogor. Kebun Raya Bogor memiliki unit yang juga menangani pelayanan jasa, yaitu Jasa Informasi dan Pemanduan yang menyediakan jasa guide. Personal sellingdapat memberikan informasi kepada pengunjung yang membutuhkan guide. Jasa Informasi dan Pemanduan menyediakan guide dalam bahasa Indonesia, Inggris, Belanda, Jerman, Jepang dan Arab. Satu orang guide bekerja maksimal dalam dua jam dengan mengelilingi kebun raya sekitar 500 meter dari pintu utama. Biaya yang harus dikeluarkan oleh pengunjung yaitu sebesar Rp. 100.000,- /guide. Berbeda halnya dengan tour guide di museum zoology yang hanya dikenakan biaya sebesar Rp. 65.000,-/guide.

Harga tiket masuk Kebun Raya Bogor yaitu Rp. 9.500,-/orang sudah termasuk tiket terusan museum Zoology dan rumah kaca anggrek. Pengunjung dapat menikmati pemandangan dan keindahan taman di Kebun Raya Bogor seperti danau, kolam teratai, jembatan merah, pohon jodoh, pemandangan Istana Bogor, dan mengetahui sejarah Kebun Raya Bogor karena banyaknya patung pendiri dan makam pendiri Kebun Raya Bogor yang berasal dari Belanda dan Jerman.

Kendaraan yang diperbolehkan masuk ke Kebun Raya Bogor hanyalah kendaraan pribadi roda empat. Pengunjung biasanya menanyakan harga tiket masuk bagi kendaraan yaitu Rp. 15.000,-/mobil. Kendaraan roda dua tidak diperbolehkan masuk karena dikhawatirkan akan merusak tanaman dan rumput yang ada di Kebun Raya Bogor. Kendaraan umum seperti bus dan angkot juga tidak diperbolehkan untuk masuk kawasan Kebun Raya Bogor, hal ini dilakukan untuk menjaga kebersihan dan menghindarkan Kebun Raya Bogor dari polusi. Bus dan kendaraan umum lainnya dapat diparkir di tempat yang telah disediakan yaitu di sekitar kantor pos yaitu pintu dua Kebun Raya Bogor atau di Damri Botani Square.

Kebun Raya Bogor juga memiliki guest house yaitu penginapan yang disewakan untuk pengunjung Kebun Raya Bogor. Guest house yaitu hunian dengan suasana Belanda yang harmonis dengan bentuk bangunan bergaya 
Eropa yang masih asli. Guest House didirikan pada tahun 1914 sebagai rumah singgah untuk penelitian oleh Dr. Malchior Treub (berkebangsaan Perancis) yang menjabat sebagai Direktur Kebun Raya Bogor pada tahun 1884. Kelebihan guest house ini adalah terdapatnya ruang makan yang luas, ruang teras untuk pertemuan, kenyamanan suasana alam yang sejuk, asri, dan tenang dengan halaman yang dipenuhi rumput hijau. Penginapan ini ditarifkan perhari sebesar Rp. 250.000,- /orang.

Kinerja personal selling dalam membantu mengoptimalkan peran humas tentunya sudah terrealisasikan dalam kegiatan Jasa Informasi dan Pelayanan. Personal selling yang bertugas di Pusat Konservasi Tumbuhan Kebun Raya Bogor menyambut masyarakat dari berbagai kalangan baik dalam negeri maupun luar negeri untuk menikmati keindahan Kebun Raya Bogor. Peran personal selling menjadi jembatan hubungan antara konsumen dan Kebun Raya Bogor dalam menjalin hubungan yang harmonis khususnya untuk masyarakat Bogor.

\section{7) Hambatan}

Hambatan yang dialami personal selling selama menjalankan tugas dan peranannya dapat diklasifikasikan sebagai hambatan nonteknis dan hambatan teknis.

\section{Hambatan non-teknis}

a. Hambatan semantik terjadi karena pemahaman yang berbeda tentang makna dan isi pesan. Perbedaan bahasa yang terjadi mengakibatkan personal selling kesulitan dalam memahami pesan yang disampaikan oleh konsumen. Kegiatan ini biasa terjadi pada saat personal selling menerima telepon dari konsumen yang berasal dari luar daerah Bogor dan wisatawan asing. Contohnya saat konsumen yang berasal dari jawa meminta informasi melalui telepon, personal selling tidak dapat berbahasa jawa. Personal selling juga pernah mendapatkan wisatawan asing berbahasa Belanda yang meminta informasi mengenai guest house, kepada personal selling.

Kegiatan ilegal adalah kegiatan yang terjadi tanpa perizinan resmi, pelanggaran ini biasanya terjadi pada kegiatan pemotretan. Kegiatan ilegal ini sering terjadi karena banyaknya pengunjung yang berminat untuk berfoto di Kebun Raya Bogor, dan tidak mengetahui peraturan yang ada. Kategori yang termasuk dalam kegiatan pemotretan non- komersil adalah jika pengunjung melakukan pemotretan dengan berganti pakaian dan ber make up. Petugas keamanan biasanya menanyakan bukti kwitansi resmi dari personal selling jika pengunjung tidak memiliki bukti lengkap maka petugas akan membawa pengunjung ke kantor personal selling, personal selling hanya meminta pengunjung untuk memberikan keterangan dan memperlihatkan hasil foto yang telah dilakukan. Jika foto memang benar dilakukan untuk kegiatan komersil maka pengunjung akan diberikan pilihan untuk membayar tarif yang sudah ditetapkan atau menghapus keseluruhan foto yang sudah diambil. Jika pengunjung memang tidak melakukan pelanggaran yang berarti foto yang diambil merupakan foto pribadi dan tidak berganti pakaian serta bermake up maka petugas personal selling akan melakukan permintaan maaf kepada pengunjung.

\section{Hambatan teknis}

a. Hambatan ini terjadi pada alat telekomunikasi yang digunakan di Jasa Informasi dan Pelayanan memiliki dua fungsi yaitu telepon dan fax, sehingga mengakibatkan lambatnya penerimaan fax.

b. Sebagian kegiatan personal selling dilakukan dengan memberikan informasi melalui telepon. Konsumen menelepon biasanya dengan waktu yang cukup lama untuk menanyakan fasilitas atau informasi seputar Kebun Raya Bogor. Kegiatan penelepon ini dilakukan pada jam oprasional Kebun Raya Bogor.

Konsumen yang berkepentingan dalam pengiriman fax untuk memberikan surat permohonan potongan harga harus menelepon terlebih dahulu untuk meminta personal selling men start telepon. Hal ini seringkali membuat konsumen harus menunggu untuk mengirim fax karena banyaknya penelepon dalam meminta informasi yang memakan waktu cukup lama. 
Rusaknya saklar menyebabkan arus listrik tidak dapat mengalir dengan baik sehingga alat telekomunikasi yang digunakan sering terputus. Saklar yang terdapat di ruangan Jasa Informasi dan Pelayanan hanya satu dan digunakan untuk seluruh kegiatan seperti telepon dan komputer. Seringnya saklar yang mati mengakibatkan kegiatan komunikasi melalui media terganggu, dalam penerimaan telepon dan fax.

\section{1) Solusi non-teknis}

a. Setiap profesi yang dimiliki oleh seseorang tentunya akan mengalami hambatan, hanya bagaimana orang itu mengatasinya. Solusi yang diperlukan dalam menangani hambatan semantik adalah bersikap professional. Bersikap professional dimaksudkan kepada personal selling harus dapat bisa mengatasi kesulitan dalam perbedaan bahasa. Personal selling berusaha memberikan penjelasan yang konsumen butuhkan dengan sedikit demi sedikit menerangkan dengan bahasa yang digunakan oleh konsumen agar konsumen dapat memahami informasi yang diberikan oleh personal selling. Dengan keanekaragaman bahasa yang dikuasai oleh personal selling menjadikan peran personla selling menjadi prosefionalitas, bahasa yang harus dikuasai adalah bahasa inggris, jepang, korea, arab, mandarin, china, dan bahasa kultur yang ada di Indonesia sendiri.

b. Solusi yang dilakukan di lapangan agar tidak terjadi kegiatan ilegal adalah personal selling membuat komunikasi internal (komin) yang ditujukan kepada pihak terkait seperti kepala Kebun Raya Bogor dan orang yang bertanggung jawab di lapangan yaitu petugas keamanan. Komin dibuat langsung oleh petugas personal selling dan ditandatangani oleh pengawas Jasa Informasi dan Pelayanan.

\section{2) Solusi Teknis}

a. Selama kegiatan berlangsung personal selling tetap menjalankan aktifitas dengan baik, walaupun terbatasi oleh fasilitas yang dapat mengganggu kegiatan personal selling. Personal selling berupaya semaksimal mungkin dalam memberikan pelayanan melalui media telepon dan fax, jika ada keluhan pelanggan dalam lamanya pengiriman $f a x$ personal selling tidak segan untuk melakukan permohonan maaf.

b. Solusi yang dilakukan oleh personal selling di lapangan adalah, melakukan pengecekan terhadap alat telekomunikasi dan alat elektronik agar komunikasi dengan konsumen tetap berjalan.

\section{KESIMPULAN}

Berdasarkan hasil dari pembahasan, maka dapat diambil kesimpulan sebagai berikut:

1) Personal selling adalah orang yang bertugas untuk mempresentasikan dan mempromosikan produk kepada konsumen. Personal selling yang baik, tidak hanya memiliki skill tetapi juga kemampuan komunikasi interpersonal yang efektif. Personal selling juga berperan untuk memberikan pelayanan secara langsung dan membangun hubungan baik dengan konsumen, serta kegiatan lain saat proses penjualan dan pemasaran jasa dan fasilitas.

2) Hambatan non-teknis yang dialami personal selling terdiri atas hambatan semantik, dan kegiatan ilegal. Hambatan eknis terdiri atas alat telekomunikasi yang terganggu dan saklar yang rusak.

\section{REFERENSI}

Adrian, Payne, (2000), Pemasaran Jasa, The Essence of Service Maerketing. Yogyakarta: Andi

Basu Swastha dan Irawan, (2000), Manajemen Pemasaran Modern, Edisi 2, Yogyakarta : Liberty.

Didih Suryadi. (2006). Promosi Efektif. Yogyakarta: Tugu Publisher

Dozier, D. M. (1992). 'The Organizational Roles of Communications and Public Relations Practitioners. Dalam J. E. Grunig (penyunting), Excellence in Public Relations and Communication Management. Hillsdale, NJ 1 Lawrence Erlbaum. 
Kenneth K. Sereno dan Edward M. Bodaken. (1975). Trans-Per Understanding Human Communication. Boston: Houghton Mifflin

Kotler, Philip dan Gary Armstrong. (2010). Principles of Marketing (Edisi 13). United States of America: Pearson.

Kotler,Philip. (2003). Marketing Management, 11th Edition. New Jersey:Prentice Hall.Inc.

Kotler . (2010). Tentang Pemasaran. Kharisma Publishing Group. Tangerang.

Machfoedz, Mahmud. (2010). Komunikasi Pemasaran Modern. Yogyakarta: Cakra Ilmu.

Moleong, Lexy. (2002). Metodologi Penelitian Kualitatif. Bandung: PT. Remaja Rosdakarya.

Mulyana, Deddy dan Rakhmat. (2009). Komunikasi Antarbudaya : Bandung: PT. Remaja Rosdakarya.
Ruslan, Rosadi. (2014). Manajemen Public Relations dan Media Komunikasi Konsep dan Aplikasinya (Edisi Revisi). Jakarta: Raja Grafindo Persada.

Soetjipto, Budi W. (1997). Service Quality. Manajemen Usahawan Lembaga Jakarta: Management FE 15 UI.

Stewart, L Tubbs \& Sylvia Moss. (1974). Human Communication: Human Communication: An Interpersonal Perspective. New York: Bantam Books.

Winardi, N. (2001). Marketing. Jakarta: Ghalia.

Yamit, Zulian, (2005), Manajemen Kualitas Produk dan Jasa. Edisi Pertama, cetakan keempat, Ekonisia, Yogyakarta: Fakultas Ekonomi UII. 